\section{Overhaul pesticide testing on bees}

Political action is needed to address the adverse side effects of systemic pesticides on bees (Nature 496, 408; 2013) by revising procedures for pesticide registration. The current risk-assessment process for these chemicals is outdated and does not incorporate important developments from the past 30 years.

To register a new pesticide in industrialized countries, the substance must be assessed for toxicity to the honeybee (Apis mellifera), which was originally chosen as a representative model of the Apoidea superfamily of some 20,000 bee species. However, the life histories of different bee species vary considerably. Unlike honeybees, most bee species are solitary, so individuals killed by pesticides are not easily replaced. There are 42 studies (source: Web of Science) reporting side effects of registered pesticides on other bee species, even though these passed risk assessment for honeybees. Tests need to be much more sensitive if they are to pick up all pesticide-related effects for bees as a whole.

Current risk assessments evaluate the survival of adult honeybees only after a short exposure to pesticide. However, numerous studies have stressed the importance of also testing for chronic toxicity, larval toxicity and sublethal effects of pesticides (N. Desneux et al. Annu. Rev. Entomol. 52, 81-106; 2007).

More rigorous pesticide testing therefore needs to include a broader range of exposure scenarios and to take relevant biological traits into account. This will stand to improve insect pollination generally, which is currently worth about $€ 153$ billion (US $\$ 202$ billion) annually worldwide (N. Gallai et al. Ecol. Econ. 68, 810-821; 2009).
Axel Decourtye Association for Technical Coordination in Agriculture (ACTA), Avignon, France.

Mickaël Henry French National Institute for Agricultural Research (INRA), Avignon, France.

Nicolas Desneux French National Institute for Agricultural Research (INRA), Sophia-Antipolis, France. nicolas.desneux@sophia.inra.fr

\section{An open dialogue on solar engineering}

We agree with Clive Hamilton that the use of geoengineering to counter climate change is a complex and controversial topic (Nature 496, 139; 2013). This is precisely why it calls for wide-ranging, open, informed and objective discussion. This applies especially to research into solar radiation management (SRM) techniques, which may be quick, cheap, effective and risky.

That is why the SRM Governance Initiative (www.srmgi.org) was created: to ensure that any research undertaken is carefully considered, safe and transparent. It is a nongovernmental organization convened by the Royal Society, the Environmental Defense Fund and TWAS, the academy of sciences for the developing world. It involves partner organizations from 16 countries, and has run meetings in Asia and Africa to seek the opinions of local members of the scientific community and others.

In the United States, the Bipartisan Policy Center in Washington DC has issued a report (see go.nature. com/13ktv7) recommending that any geoengineering research programme should be supported by research governance that incorporates transparent peer-review and public deliberation.

A growing community of scientists and stakeholders are already taking into consideration the serious implications of SRM technologies for governance, ethics and politics.

John Shepherd University of

Southampton, UK.

jgs@noc.soton.ac.uk

Berhanu Abegaz African

Academy of Sciences, Nairobi,

Kenya.

Jane Long Bipartisan Policy

Center, Washington DC; and

Environmental Defense Fund,

San Francisco, California, USA.

\section{Oil-palm concerns in Brazilian Amazon}

Brazil's Environmental Council of Pará State (COEMA) is debating a resolution to the new Brazilian Forest Code that will help to define 'low-impact' land uses in legally designated areas of permanent protection (APPs). One proposal is that plantations of oil palm (Elaeis guineensis), which are rapidly expanding in the eastern Amazon, might offer a sustainable option for restoring permanently protected areas. We have some concerns about this proposal.

Evidence from across the tropics (E. B. Fitzherbert et al. Trends Ecol. Evol. 23, 538-545; 2008) shows that oil-palm plantations have a considerable impact on the environment because they require substantial agrochemical inputs and host few native species. Therefore, oil-palm plantations must not be allowed to displace natural forest vegetation and should not count as a component of the legally required forest reserves on private land.

We suggest that any approval from the COEMA that officially designates oil palm as a lowimpact crop should await a full investigation into the biological and social effects of oil-palm cultivation in APPs. This will ensure that the biological function of these ecologically sensitive regions is not compromised, as the law demands.

Several other areas in Brazil would be more suitable for oil palm - particularly degraded land, where the impact on biodiversity would be minimal Alexander C. Lees, Ima C. G. Vieira Emílio Goeldi Museum, Belém, Pará, Brazil. alexanderlees@btopenworld.com

\section{Non-coding RNA foreseen 48 years ago}

The recent enthusiasm for studying non-coding RNAs (Nature 496, 127-129; 2013) brings to mind a largely forgotten review article that I wrote almost half a century ago in Evolving Genes and Proteins (V. Bryson and H. J. Vogel (eds) 469; Academic Press, 1965). This review reached a conclusion that was judged to be profoundly heretical at the time.

The article summarized years of work on the turnover of nuclear RNA, carried out during a period when pulse-labelled RNA was almost universally misdiagnosed as messenger RNA. It concluded: "Only a small proportion of the RNA made in the nucleus of animal and higher plant cells serves as a template for the synthesis of protein. This RNA is characterised by its ability to assume a form which protects it from intracellular degradation. Most of the nuclear RNA, however, is made on parts of the DNA which do not contain information for the synthesis of specific proteins. This RNA does not assume the configuration necessary for protection from degradation and is eliminated." Henry Harris University of Oxford, UK. henry.harris@path.ox.ac.uk

\section{CORRECTION}

The Comment article 'Choose satellites to monitor deforestation' (Nature 496, 293-294, 2013) wrongly stated that more than one billion people in the tropics depend on forests. In fact, it is more than one billion people worldwide. 